\title{
A comparative study on handle properties of bamboo and cotton fabrics
}

DOI: $10.35530 / I T .070 .03 .1538$

GAMZE SÜPÜREN MENGÜÇ

EYLEN SEMA DALBAŞI

ARIF TANER ÖZGÜNEY

NILGÜN ÖZDIL

\author{
REZUMAT - ABSTRACT
}

Studiu comparativ al tușeului țesăturilor din bambus și bumbac

Emolienții sunt de mare importanță în prelucrarea textilelor. Scopul acestui tratament este de a obține un tușeu moale pentru a facilita capacitatea de prelucrare și a îmbunătăți gradul de uzură. În acest studiu, s-a urmărit investigarea efectului și durabilității spălării diferiților emolienți asupra proprietăților tușeului țesăturilor tricotate din bumbac și bambus. Au fost aplicate șase tipuri de emolienți pe țesături. Mai mult, a fost testată durabilitatea tratării cu emolienți după 5,10 și 20 cicluri de spălare. Au fost măsurate caracteristicile tușeului, cum ar fi: drapajul, coeficientul de frecare cinetică și rigiditatea la indoire circulară. Rezultatele au fost evaluate statistic. S-a constatat că tratamentul de emoliere nu are o performanță de succes pentru țesăturile de bambus, așa cum se întâmplă în cazul țesăturilor de bumbac.

Cuvinte-cheie: bumbac, bambus, emolient, drapaj, frecarea suprafeței, spălare

A comparative study on handle properties of bamboo and cotton fabrics

Softeners are of great importance in textile processing. The aim of this treatment is to achieve a soft handle to facilitate the processability and improve wettability. In this study, it was aimed to investigate the effect and washing durability of various softeners on handle properties of cotton and bamboo knitted fabrics. Six types of softeners were applied to the fabrics. Moreover, the washing durability of the softeners after 5, 10 and 20 washing cycles were tested. Handle characteristics such as drapeability, kinetic friction coefficient and circular bending rigidity were measured. The results were statistically evaluated. It was determined that softening treatment does not have a successful performance in bamboo fabrics as it has in cotton fabrics.

Keywords: cotton, bamboo, softener, drapeability, surface friction, washing

\section{INTRODUCTION}

Cotton is one of the most commonly used textile fibers in the world. It is comfortable and has soft handle, good color and printing properties. It is predicted that cotton's consumption will be approximately 30 million tons by 2020 [1-6].

A regenerated cellulosic fiber bamboo has recently been of great interest due to its several advantages. Bamboo fibers have good characteristics such as moisture vapor transmission, good dyeability, soft hand, high moisture absorption capacity and pleasant luster. Bamboo fiber is consisted of cellulose (57-63\%) with a $\alpha$-cellulose content of $36-41 \%$, lignins (22-26\%) and penthosans (16-21\%) [7-10]. Softeners can provide textiles an agreeable soft hand, some smoothness, more flexibility, better drape and pliability. Softeners are classified according to their ionic character as cationic, anionic, non-ionic, amphoteric, and silicone [11-13]. The hydrophilic parts of the cationic softener contain quaternary ammonium, which adsorb negatively charged fiber surfaces. The long aliphatic chains are then oriented towards outside of the fiber and act as an excellent boundary lubricant between yarns and fibers [14].

Anionic softeners have nowadays only a very limited use in textile processing, due to their low substantivity and minor softness. Some examples of their uses include raising and sanforising processes, which result in improved smoothness/antistatic and rewetting properties, respectively.

Non-ionic softeners theoretically have no electric charge and for that reason show no significant substantivity. They can be easily combined with other active agents or products, are stable against high temperatures and are non-yellowing. For that reason, this product group is ideal for the finish of opticallybrightened white textiles [15].

Silicones became popular in the textile industry in the early 1960s. The first products were mainly polydimethylsiloxanes without modification. A breakthrough came in the 1970s with the development of aminofunctional polydimethylsiloxanes, which are the most advanced silicone softeners [16]. Silicones are polymers with backbones that consist of alternating oxygen and silicon atoms. The silicon-oxygen bonds are strong and very flexible compared to the carboncarbon bonds found in the backbones of other polymers. The general structure of the silicone softener can be seen in figure 1 .

The flexibility of the siloxane backbone means that at an interface the methyl groups can always be presented to the outside world, creating a very low surface energy material. The silicone softeners are classified as polydimethylsiloxanes, amido, amino functional silicones, methyl hydrogen silicones, epoxy functional silicones, hydroxyl functional silicones, silicone polyethers, epoxy polyether silicones [17-19]. 


$\begin{gathered}\mathrm{Me} \\ 1 \\ \text { Reactive Group - } \mathrm{Si} \\ 1 \\ \mathrm{Me}\end{gathered} \quad \mathrm{O}-\left[\begin{array}{l}\text { Reactive Group } \\ 1 \\ \mathrm{Si}-\mathrm{O} \\ 1 \\ \text { Functional Group }\end{array}\right]\left[\begin{array}{l}\mathrm{Me} \\ 1 \\ \mathrm{Si}-\mathrm{O}- \\ 1 \\ \mathrm{Me}\end{array}\right] \mathrm{Si}$ - O - Reactive Group

Fig. 1. General structure of a silicone softener [17]

Functional group: Amino Ethyl, Amino Propyl, Amido, Glycol, Vinyl, Quaternary, Hydroxyl

Reactive group: Methoxy, Ethoxy, $\mathrm{OH}, \mathrm{H}$ $\mathrm{X}, \mathrm{Y}$ : number of monomeric units

According to the literature review, it can be stated that, there are several studies indicating the effect of softeners on cotton fabrics [13, 15, 20-22]. However, there is not a comprehensive research, which includes cationic, non-ionic, anionic softeners and silicones on bamboo fabrics. Therefore, the importance of this study is to investigate systematically the effects of different softeners on drape and friction properties of cotton and bamboo knitted fabrics. Furthermore, the washing durability of the used softeners after 5, 10 and 20 washing cycles were examined.

\section{MATERIALS AND METHODS}

In this study $100 \%$ cotton and $100 \%$ bamboo (regenerated) yarns in 20 Tex yarn count and in $\alpha_{m}=120$ twist coefficient were used. They were knitted in interlock structure in the same density $(27 \mathrm{wpc}$ and $15 \mathrm{cpc}$ ) by using the FOUQUET 18E gauge knitting machine.
After the fabrics were pre-treated and dyed, six different softeners were applied to these fabrics by padding method. All the softeners were commercial chemicals supplied from Rudolf Duraner Company.

Rapid Model PA-1 marked laboratory padder was used for impregnation and Ataç GK4 marked laboratory stenter was used for drying. The chemical structures and types of used softeners and the application recipes are given in table 1 .

After the applications, the untreated and treated samples were washed at the Wascator machine according to ISO 6330 standard (5A program) and dried by lying. The washing cycles were selected as 5,10 and 20.

Before the tests, fabric samples were conditioned under standard atmosphere conditions $\left(20^{\circ} \mathrm{C} \pm 2^{\circ} \mathrm{C}\right.$ temperature, $65 \% \pm 4 \% \mathrm{RH}$ ). Afterwards, characteristics such as thickness, mass per unit area, drapeability, friction coefficients, circular bending rigidity were measured.

The fabric drapeability test was carried out by using Cusick Drape Tester according to BS EN ISO 9073-9 (figure 2,a). The fabric drapeability tests were repeated six times. In the drape test, a circular specimen is held concentrically between two smaller horizontal discs and is allowed to drape into folds under its own weight. A light is shone from underneath the specimen and the shadow that of the fabric casts. The stiffer a fabric is, the larger is the area of its shadow compared with the unsupported area of the fabric.

Table 1

\begin{tabular}{|l|l|l|}
\hline \multicolumn{3}{|c|}{ THE APPLICATION RECIPES OF THE SOFTENERS } \\
\hline \multicolumn{1}{|c|}{ Definition } & \multicolumn{1}{|c|}{ Softener type } & \multicolumn{1}{c|}{ Treatment conditions } \\
\hline UT & Untreated fabric (only pretreated and dyed fabric) & - \\
\hline Softener 1 (S1) & Micro-dispersed poly-amino siloxane & $30 \mathrm{~g} / \mathrm{l}, \mathrm{pH}: 5.5-6$ (Acetic acid) \\
\hline Softener 2 (S2) & Macro-emulsion of elastomeric poly-amino siloxane & $30 \mathrm{~g} / \mathrm{l}, \mathrm{pH}: 4.5-5.5$ (Acetic acid) \\
\hline Softener 3 (S3) & Nano-emulsion of elastomeric polyaminosiloxane & $30 \mathrm{~g} / \mathrm{l}, \mathrm{pH}: 4.5-5$ (Acetic acid) \\
\hline Softener 4 (S4) & Cationic softener, Carbamide derivative & $30 \mathrm{~g} / \mathrm{l}, \mathrm{pH}: 4-5$ (Acetic acid) \\
\hline Softener 5 (S5) & Nonionic softener, Polyethylene emulsion & $30 \mathrm{~g} / \mathrm{l}, \mathrm{pH}: 6-7$ (Acetic acid) \\
\hline Softener 6 (S6) & Carbamino derivative and reactive polysiloxanes & $30 \mathrm{~g} / \mathrm{l}, \mathrm{pH}: 4.5-5$ (Acetic acid) \\
\hline Impregnation conditions: Pick up value: 75 \%, Drying: 130C for 3 min. & \\
\hline
\end{tabular}

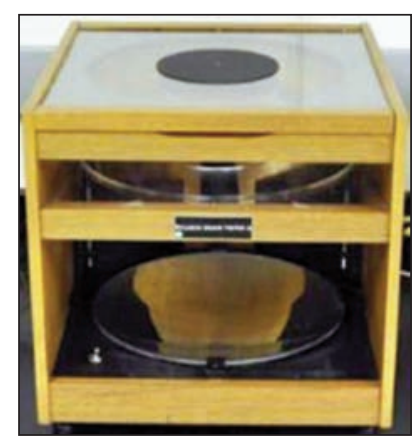

a

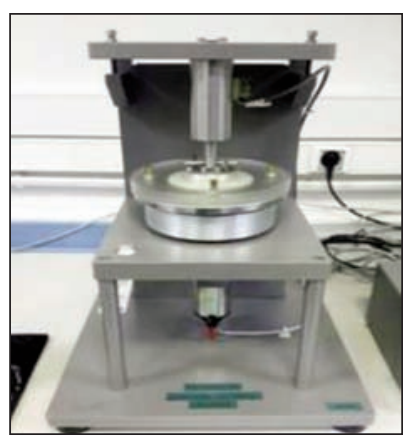

b

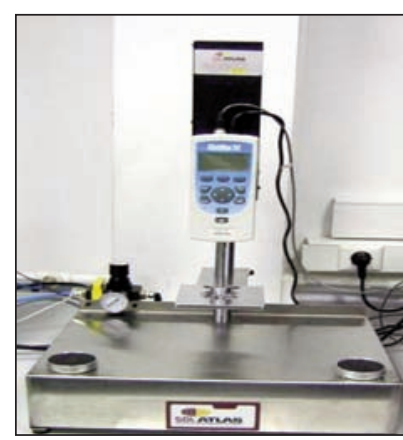

c

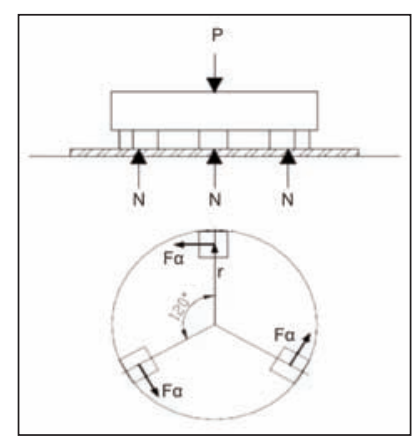

d

Fig. 2. Cusick Drape Tester (a), Frictorq instrument (b), SDL Atlas Digital Pneumatic Stiffness Tester (c), measurement principle of Frictorq $(d)$ 
The drape coefficient can then be calculated using the following equation:

Drape coefficient $=\frac{\text { mass of shaded area }}{\text { total } \text { mass of paper ring }} \times 100$

The higher the drape coefficient a fabric has, the lower drapeability and stiffer the fabric gets.

The circular bending rigidity of the fabrics was tested with SDL Atlas Digital Pneumatic Stiffness Tester (figure 2,c). During test some of the specimens could not be measured due to the low force value. In order to compare the stiffness values of the fabrics, six samples were prepared for each type of fabric according to ASTM D 4032 standard [24, 25].

In order to determine the kinetic friction coefficient of the experimental fabrics, Frictorq instrument (figure $2, b)$, which uses the torq principle was employed. Instrument is designed to measure the Coefficient of Friction, $\mu$, in 2D flexible structures such as woven fabrics, knitted fabrics, nonwovens and soft papers (tissue). In this model, friction coefficient is calculated from the friction reaction torque measured by means of a high sensitivity torque sensor, the normal load created by the contact sensor and a geometrical parameter (figure 2, $d$ ).

$$
T=3 F_{a} r
$$

Being, by definition, $F_{a}=\mu N$ and from figure 2, $d$, $N=P / 3$, where $P$ is the vertical load, the coefficient of friction is then expressed by [23]:

$$
\mu=\frac{T}{P \cdot r}
$$

After the drapeability, friction coefficient and circular bending rigidity measurements, the obtained results were evaluated statistically. ANOVA and StudentNewman-Keuls tests were conducted to determine whether the effect of fabric type, softening agents and washing cycles on fabric properties are statistically significant at $95 \%$ confidence level $(p<0.05)$

\section{RESULTS AND DISCUSSION}

\section{Dimensional properties results}

Results of mass per unit area and thickness properties of the fabrics are given in table 2 .

\begin{tabular}{|c|c|c|c|c|c|}
\hline \multirow{2}{*}{ Softener type } & & \multicolumn{2}{|c|}{ Mass per unit area $\left(\mathrm{g} / \mathrm{m}^{2}\right)$} & \multicolumn{2}{|c|}{ Thickness (mm) } \\
\hline & & BAMBOO & COTTON & BAMBOO & COTTON \\
\hline \multirow{4}{*}{ UT } & Before washing & 170.0 & 167.6 & 0.93 & 1.01 \\
\hline & 5 washing cycle & 171.9 & 174.7 & 1.03 & 1.14 \\
\hline & 10 washing cycle & 172.2 & 174.4 & 1.05 & 1.14 \\
\hline & 20 washing cycle & 169.2 & 173.0 & 1.04 & 1.12 \\
\hline \multirow{4}{*}{ S1 } & Before washing & 159.7 & 165.5 & 0.85 & 0.96 \\
\hline & 5 washing cycle & 156.4 & 172.7 & 1.00 & 1.14 \\
\hline & 10 washing cycle & 165.3 & 176.9 & 1.01 & 1.15 \\
\hline & 20 washing cycle & 173.0 & 171.4 & 1.08 & 1.12 \\
\hline \multirow{4}{*}{$\mathrm{S} 2$} & Before washing & 159.2 & 170.0 & 0.85 & 0.96 \\
\hline & 5 washing cycle & 170.6 & 182.3 & 1.05 & 1.16 \\
\hline & 10 washing cycle & 158.9 & 182.9 & 1.00 & 1.18 \\
\hline & 20 washing cycle & 163.7 & 182.3 & 1.07 & 1.15 \\
\hline \multirow{4}{*}{ S3 } & Before washing & 160.8 & 168.6 & 0.76 & 0.99 \\
\hline & 5 washing cycle & 170.2 & 181.1 & 0.98 & 1.15 \\
\hline & 10 washing cycle & 170.8 & 178.0 & 1.05 & 1.14 \\
\hline & 20 washing cycle & 161.8 & 168.6 & 1.00 & 1.10 \\
\hline \multirow{4}{*}{ S4 } & Before washing & 156.7 & 166.0 & 0.80 & 0.97 \\
\hline & 5 washing cycle & 165.6 & 171.4 & 1.02 & 1.14 \\
\hline & 10 washing cycle & 165.9 & 173.9 & 1.02 & 1.14 \\
\hline & 20 washing cycle & 169.3 & 168.3 & 1.01 & 1.07 \\
\hline \multirow{4}{*}{ S5 } & Before washing & 160.5 & 163.2 & 0.81 & 0.94 \\
\hline & 5 washing cycle & 177.3 & 174.1 & 1.12 & 1.11 \\
\hline & 10 washing cycle & 177.3 & 173.9 & 1.14 & 1.13 \\
\hline & 20 washing cycle & 175.8 & 176.8 & 1.10 & 1.11 \\
\hline \multirow{4}{*}{ S6 } & Before washing & 159.4 & 161.2 & 0.77 & 0.96 \\
\hline & 5 washing cycle & 170.3 & 176.4 & 1.01 & 1.11 \\
\hline & 10 washing cycle & 173.3 & 172.4 & 1.06 & 1.12 \\
\hline & 20 washing cycle & 169.5 & 171.5 & 1.09 & 1.08 \\
\hline
\end{tabular}

DIMENSIONAL PROPERTIES OF THE FABRICS AFTER SOFTENING TREATMENT AND WASHING CYCLES 
According to the results it can be stated that, fabric weight and thickness increase after washing processes. It is due to the shrinkage of the fabric, which occurs during the repeating washing cycles for all types of materials. Shrinkage is highest especially after the first 5 washing cycles. However, the mass and thickness generally decrease after the repeating washings.

\section{Drape coefficient results}

In order to determine the effect of softener types more sensitively, statistical evaluation was conducted on the results of the unwashed fabrics titled as "Before washing". Statistical evaluation of the washing and softeners effect on fabric drape was given in table 3 and table 4 respectively. It can be said that there is a significant difference between cotton and bamboo fabrics and washing cycles has an effect on the drape coefficient of the fabrics.

Table 3

\section{EFFECT OF FABRIC TYPE AND WASHING CYCLE ON FABRIC DRAPE}

\begin{tabular}{|c|c|c|c|c|c|}
\hline \multicolumn{3}{|c|}{ Fabric type } & \multicolumn{3}{|c|}{ Sig. } \\
\hline \multicolumn{3}{|c|}{ Bamboo fabrics } & \multirow{2}{*}{\multicolumn{3}{|c|}{0,000}} \\
\hline \multicolumn{3}{|c|}{ Cotton fabrics } & & & \\
\hline \multicolumn{6}{|c|}{ DRAPE COEFFICIENT } \\
\hline \multirow{2}{*}{$\begin{array}{c}\text { Washing } \\
\text { cycle }\end{array}$} & \multirow{2}{*}{$\mathbf{N}$} & \multicolumn{4}{|c|}{ Subset } \\
\hline & & 1 & 2 & 3 & \\
\hline 0 & 96 & 11.2 & & & \\
\hline 5 & 96 & & 13.3 & & \\
\hline 10 & 96 & & & 15.3 & \\
\hline 20 & 96 & & & & 17.9 \\
\hline Sig. & & 1.000 & 1.000 & 1.000 & 1.000 \\
\hline
\end{tabular}

Drape coefficient values of the bamboo fabrics are given in figure 3 . It is clearly seen that all bamboo fabrics have lower drape coefficient than cotton fabrics, indicating the high bending behavior and softness of the material. Because the lower the drape coefficient value is, the softer the fabric is. As the drape coefficient test results were analyzed in detail, it can be seen that washing process causes increase of the drape coefficient for both cotton and bamboo fabrics. It can be stated that the fabrics became stiffer

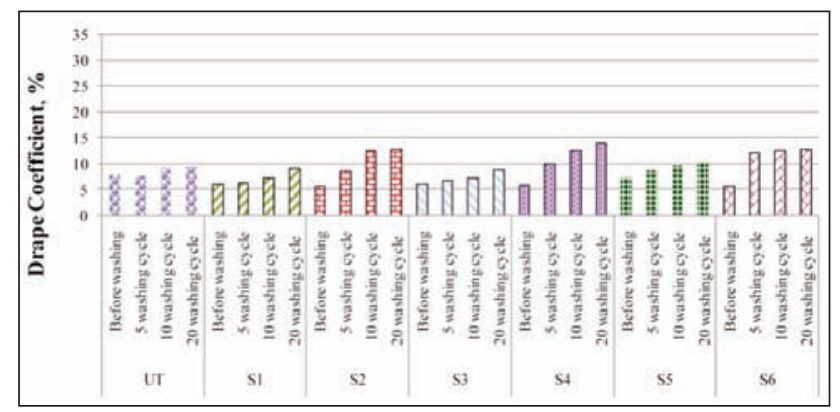

Fig. 3. Drape coefficient values of the bamboo fabrics

\begin{tabular}{|c|c|c|c|c|c|}
\hline & & & & & Table 4 \\
\hline EFF & ECT OF SOFTENE & TY & ON FA & BRIC D & RAPE \\
\hline & DRA & $\mathrm{CO}$ & FICIEI & & \\
\hline 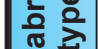 & Softener & $\mathbf{N}$ & & Subset & \\
\hline & type & & 1 & 2 & 3 \\
\hline & S6 & 6 & 5.67 & & \\
\hline of & S2 & 6 & 5.81 & & \\
\hline$\overline{\underline{m}}$ & S4 & 6 & 5.87 & & \\
\hline 巡 & S1 & 6 & 6.07 & & \\
\hline ○ & S3 & 6 & 6.07 & & \\
\hline$\sum$ & S5 & 6 & & 7.37 & \\
\hline m & Without softener & 6 & & 7.85 & \\
\hline & Sig. & & 0.499 & 0.063 & \\
\hline & S1 & 6 & 12.90 & & \\
\hline & S6 & 6 & & 14.78 & \\
\hline$\overline{\underline{n}}$ & S4 & 6 & & 14.92 & \\
\hline 近 & S3 & 6 & & 15.45 & \\
\hline z & S2 & 6 & & 15.64 & \\
\hline 点 & S5 & 6 & & 15.90 & \\
\hline 0 & Without softener & 6 & & & 24.32 \\
\hline & Sig. & & 1.000 & 0.094 & 1.000 \\
\hline
\end{tabular}

after washing process. The effect was found statistically significant (figure 2 and table 3 ). In case of softener, it can be stated that the fabrics became stiffer after washing process. Additionally, there is not a statistically significant change in fabric drapeability after the softening treatments for bamboo fabrics except the fabrics treated with softening agent S5, which is a nonionic softener.

Cotton fabrics exhibited the highest drape coefficient within all fabrics (figure 4). Compared to the bamboo fabrics, the effect of softeners can be seen clearly.

Drape coefficient values decrease after softening treatment for cotton fabrics as well. Softener S1, which is micro-silicone, has the highest effect among them. It was thought that after washing, micro-silicones cannot move away from fabric due to the low molecule size. Similar to the results of bamboo fabrics, softener S5 provided the lowest effect. Increased washing cycles causes increases in fabric stiffness as well.

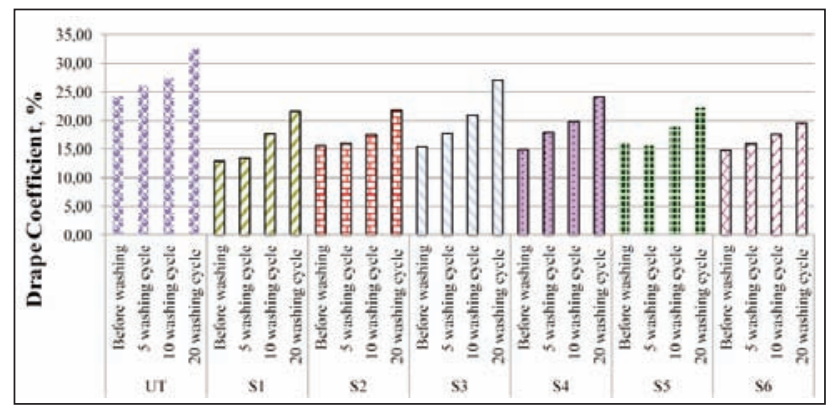

Fig. 4. Drape coefficient values of cotton fabrics 
Statistical evaluation of the effect of washing and softeners on friction properties of fabrics were given in table 5 and table 6 respectively. It can be said that there is a significant difference between cotton and bamboo fabrics and washing cycles have an effect on the friction coefficient of the fabrics.

Table 5

EFFECT OF FABRIC TYPE AND WASHING CYCLE ON FRICTION COEFFICIENT

\begin{tabular}{|c|c|c|c|c|}
\hline \multicolumn{3}{|c|}{ Fabric type } & \multicolumn{2}{c|}{ Sig. } \\
\hline \multicolumn{3}{|c|}{ Bamboo fabrics } & \multicolumn{2}{c|}{0,002} \\
\hline \multicolumn{3}{|c|}{ Cotton fabrics } & $\mathbf{3}$ \\
\hline \multicolumn{3}{|c|}{ FRICTION COEFFICIENT } \\
\cline { 1 - 3 } $\begin{array}{c}\text { Washing } \\
\text { cycle }\end{array}$ & $\mathbf{N}$ & $\mathbf{1}$ & $\mathbf{2}$ & $\mathbf{3}$ \\
\hline 0 & 84 & 0.3353 & & \\
\hline 20 & 84 & 0.3404 & & 0.3609 \\
\hline 10 & 84 & & 0.3530 & 1.000 \\
\hline 5 & 84 & & & 1.000 \\
\hline Sig. & & 0.056 & \\
\hline
\end{tabular}

According to the table 6 softening treatment do not increase surface smoothness, conversely increase the surface friction in most cases for bamboo fabrics. However, in cotton fabrics softening treatment provide significant decrease on surface friction.

Kinetic friction coefficient values of the fabrics were given in figure 5 and figure 6 . In case of washing cycles, kinetic friction coefficient values increased after 5 washing cycles and as the washing cycles increased, decline tendency was determined. These results were found parallel to the results of mass per unit area and it is due to the shrinkage of the fabrics. The shrinkage is higher after 5 times of washing, however, after 10 washing cycles hairiness on fabric surface is removed and surface fuzzes decrease. As a result of that, friction coefficient values decrease. As the effect of the softening agent was examined for unwashed fabrics, it can be stated that softening treatment causes an increase in the surface friction coefficient of the fabrics except for softening agent S6. The effect of softening treatment on friction coefficient of cotton fabrics can be seen in figure 6 . As all

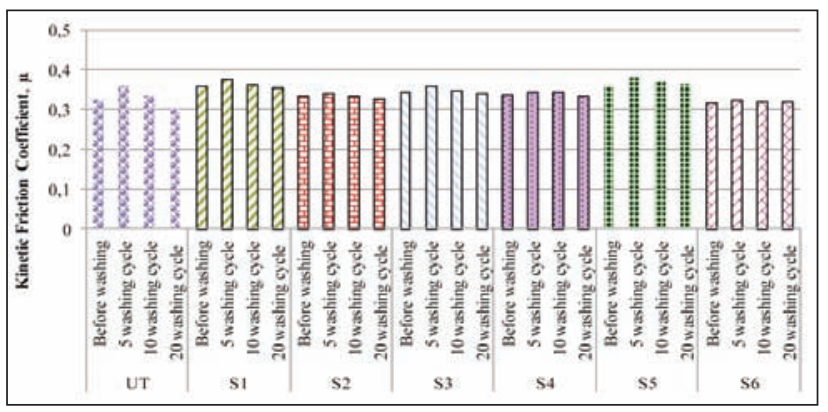

Fig. 5. Kinetic friction coefficient values of bamboo fabrics

\begin{tabular}{|c|c|c|c|c|c|c|}
\hline \multirow{4}{*}{ 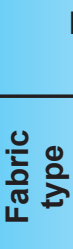 } & FECT OF & $\begin{array}{l}\mathrm{FTI} \\
\mathrm{CO}\end{array}$ & $\begin{array}{l}\text { NER T } \\
\text { FFICIE }\end{array}$ & $\begin{array}{l}\text { PE ON } \\
\text { NT }\end{array}$ & FRICTI & \\
\hline & \multicolumn{6}{|c|}{ FRICTION COEFFICIENT } \\
\hline & \multirow{2}{*}{$\begin{array}{c}\text { Softener } \\
\text { type }\end{array}$} & \multirow{2}{*}{$\mathbf{N}$} & \multicolumn{4}{|c|}{ Subset } \\
\hline & & & 1 & 2 & 3 & 4 \\
\hline \multirow{8}{*}{ 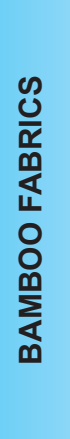 } & S6 & 6 & 0.318 & & & \\
\hline & $\begin{array}{l}\text { Without } \\
\text { softener }\end{array}$ & 6 & 0.323 & & & \\
\hline & $\mathrm{S} 2$ & 6 & & 0.333 & & \\
\hline & S4 & 6 & & 0.337 & 0.337 & \\
\hline & S3 & 6 & & & 0.344 & \\
\hline & $\mathrm{S} 1$ & 6 & & & & 0.358 \\
\hline & S5 & 6 & & & & 0.360 \\
\hline & Sig. & & 0.217 & 0.281 & 0.051 & 0.473 \\
\hline \multirow{8}{*}{ 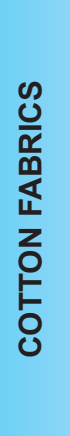 } & $\mathrm{S} 2$ & 6 & 0.319 & & & \\
\hline & S3 & 6 & 0.320 & & & \\
\hline & S4 & 6 & 0.322 & & & \\
\hline & S5 & 6 & & 0.332 & & \\
\hline & S6 & 6 & & 0.332 & & \\
\hline & S1 & 6 & & & 0.340 & \\
\hline & $\begin{array}{l}\text { Without } \\
\text { softener }\end{array}$ & 6 & & & & 0.350 \\
\hline & Sig. & & 0.713 & 0.958 & 1.000 & 1.000 \\
\hline
\end{tabular}

unwashed fabrics were considered, softeners S2, S3 and $\$ 4$ cause the highest decrease on the friction coefficient of the fabrics. This type of softeners provide smooth fabric surface. Softeners S5 and S6 have a moderate effect on decrease. Softener 1 has the lowest effect. However, it can be interpreted that softening treatment for cotton fabrics is effective in terms of kinetic friction coefficient. The change of the kinetic friction coefficients depending on the washing cycles are generally in the same tendency for all softener types and the changes are related with the fabric shrinkage. Softener 1 and 5 are not efficient on the surface properties of any of these fabrics.

\section{Circular bending rigidity test results}

Statistical evaluation of the effect of washing and softeners on bending rigidity properties of the fabrics was given in table 7 and table 8 respectively. It can

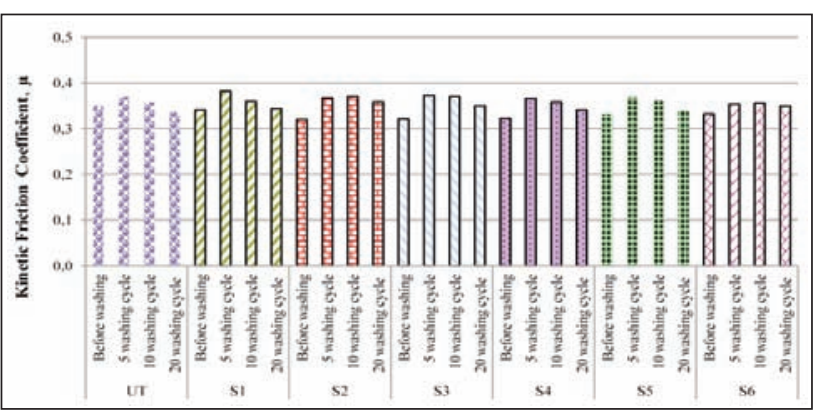

Fig. 6. Kinetic friction coefficient values of cotton fabrics 
be said that there is a significant difference between cotton and bamboo fabrics and washing cycles has an effect on the bending behavior of the fabrics.

Table 7

\begin{tabular}{|c|c|c|c|c|c|}
\hline \multicolumn{2}{|c|}{ Fabric type } & \multicolumn{3}{c|}{ Sig. } \\
\hline \multicolumn{3}{|c|}{ Bamboo fabrics } & \multicolumn{3}{c|}{0,000} \\
\hline \multicolumn{3}{|c|}{ Cotton fabrics } & \multicolumn{3}{c|}{ Subset } \\
\hline \multicolumn{5}{|c|}{ CIRCULAR BENDING RIGIDITY } \\
\cline { 1 - 5 } $\begin{array}{c}\text { Washing } \\
\text { cycle }\end{array}$ & $\mathbf{N}$ & $\mathbf{1}$ & $\mathbf{2}$ & $\mathbf{3}$ & $\mathbf{4}$ \\
\hline 0 & 42 & 3.02 & & & \\
\hline 5 & 42 & & 5.67 & & \\
\hline 10 & 42 & & & 6.85 & \\
\hline 20 & 42 & & & & 7.60 \\
\hline Sig. & & 1.000 & 1.000 & 1.000 & 1.000 \\
\hline
\end{tabular}

Table 8

\begin{tabular}{|c|c|c|c|c|c|c|}
\hline \multirow{3}{*}{ 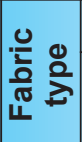 } & \multicolumn{6}{|c|}{ CIRCULAR BENDING RIGIDITY } \\
\hline & \multirow{2}{*}{$\begin{array}{l}\text { Softener } \\
\text { type }\end{array}$} & \multirow{2}{*}{$\mathbf{N}$} & \multicolumn{4}{|c|}{ Subset } \\
\hline & & & 1 & 2 & 3 & 4 \\
\hline \multirow{8}{*}{ 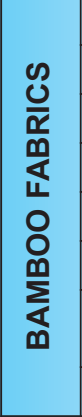 } & S3 & 3 & 1.10 & & & \\
\hline & S6 & 3 & 1.13 & & & \\
\hline & $\mathrm{S} 1$ & 3 & 1.23 & & & \\
\hline & S4 & 3 & 1.25 & & & \\
\hline & $\mathrm{S} 2$ & 3 & 1.33 & & & \\
\hline & S5 & 3 & & 1.75 & & \\
\hline & $\begin{array}{l}\text { Without } \\
\text { softener }\end{array}$ & 3 & & & 2.30 & \\
\hline & Sig. & & 0.072 & 1.000 & 1.000 & \\
\hline \multirow{8}{*}{ 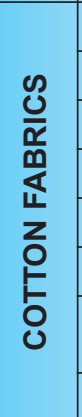 } & S1 & 3 & 3.62 & & & \\
\hline & S4 & 3 & 4.17 & 4.17 & & \\
\hline & S3 & 3 & 4.32 & 4.32 & & \\
\hline & S2 & 3 & 4.35 & 4.35 & & \\
\hline & S6 & 3 & & 4.53 & & \\
\hline & S5 & 3 & & & 4.90 & \\
\hline & $\begin{array}{l}\text { Without } \\
\text { softener }\end{array}$ & 3 & & & & 6.40 \\
\hline & Sig. & & 0.061 & 0.088 & 1.000 & 1.000 \\
\hline
\end{tabular}

Circular bending rigidity results of the fabrics were given in figure 7 and figure 8 . As the circular bending rigidity of the fabrics increases, fabric becomes stiffer. For all fabric types, circular bending rigidity gets higher as the washing cycles increase. It was determined that, cotton fabrics have higher circular bending rigidity than bamboo fabrics. It can be seen that all softeners have a significant effect on fabric rigidity, while softener S5 has the least influence. This is related with the lower substantivity of the non-ionic softener. The orientation of non-ionic softeners depends on the nature of the fiber surface, with the hydrophilic portion of the softener being attracted to hydrophilic surfaces and the hydrophobic portion being attracted to hydrophobic surfaces [11]. Similar

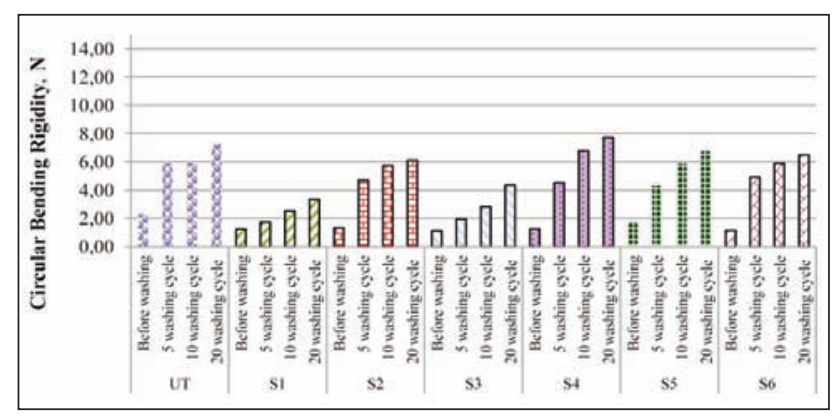

Fig. 7. Circular bending rigidity values of bamboo fabrics

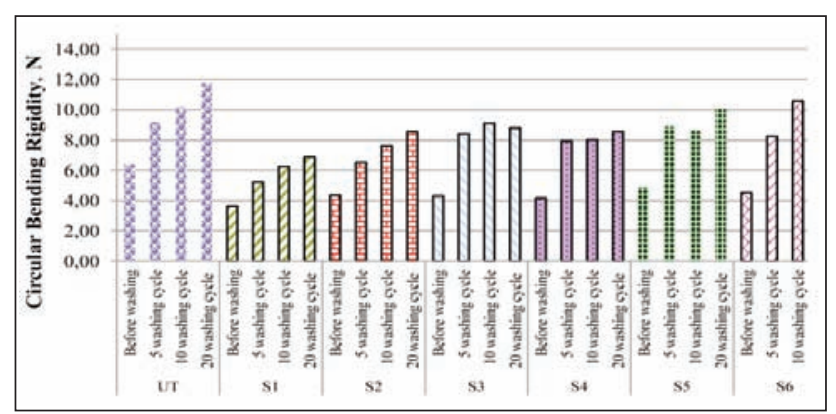

Fig. 8. Circular bending rigidity values of cotton fabrics

to the drape results except softener S5, there is not a significant effect of softener type on bending rigidity of bamboo fabrics.

\section{CONCLUSIONS}

Softening treatment is one of the most important processes in textile finishing. In this study, the purpose is to investigate washing durability and effect of various softeners on drape, kinetic friction coefficient and bending rigidity properties of cotton and bamboo knitted fabrics systematically. The obtained results can be summarized as follows:

- Bamboo fabrics and its blends have very soft handle and a smooth surface, whereas cotton fabrics are comparatively stiffer and have rougher surfaces. It was determined that softening treatment does not have the same effective softening performance on bamboo fabrics as it has on cotton fabrics. According to the circular bending rigidity results all softeners have a significant effect on fabric rigidity except softener 5 .

- The fabric weight and thickness increased after washing processes due to the shrinkage of the fabric.

- While softener 6 (carbamino derivative and reactive polysiloxanes) had better performance for bamboo fabrics, softener 1 (micro-silicone) was more efficient for cotton fabrics.

- An increase was found in kinetic friction coefficient of bamboo fabrics after softening treatment. It is thought that this result is related with the increase of fuzzes on the surface and shrinkage of the fabrics. Therefore, softening treatment did not have a positive effect on surface properties. However, for cotton fabrics, softening treatment was found to have a significant effect on kinetic friction coefficient. Treatment with softener 2 (macro siloxane), 
softener 3 (nano siloxane) and softener 4 (cationic), reduced the kinetic friction coefficient, which provides a smoother surface and a better frictional feeling.

\section{ACKNOWLEDGEMENT}

The authors give their special thanks to "Cotton Incorporated" for their financial support in supplying of cotton yarns and testing services.

\section{BIBLIOGRAPHY}

[1] Cook, J.G. Handbook of Textile Fibres, Vol.1: Natural Fibres, $5^{\text {th }}$ ed., Merrow Publishing, Shildon, England (1984).

[2] Carty, P. Fibre properties, $3^{\text {rd }}$ ed. Pentaxion Publishing, UK (1996).

[3] Miles, L. Focus on Cotton, Wayland Publishers Ltd, England (1986).

[4] Becerra, C.A.V. World cotton demand in the future: Issues on competitiveness, In: $25^{\text {th }}$ International Cotton Conference, Bremen, Germany, March 2 (2000).

[5] Shamey, R., Hussein, T. Critical solutions in the dyeing of cotton textile materials, In: Text Prog, 37, 1 (2005).

[6] http://www.ica-hk.org, (2014).

[7] Xu, Y., Lu, Z., Tang, R. Structure and thermal properties of bamboo viscose, tencel and conventional viscose fiber, In: J Therm Anal Calorim, 89, 197 (2007).

[8] Tausif, M., Ahmad, F., Hussain, U., Basit, A., Hussain, T. A comparative study of mechanical and comfort properties of bamboo viscose as an eco-friendly alternative to conventional cotton fibre in polyester blended knitted fabrics, In: J Clean Prod J, 89, 110 (2015).

[9] Lipp-Symonowicz, B., Sztajnowski, S., Wojciechowska, D. New commercial fibres called 'Bamboo Fibres' - Their structure and properties, In: Fibres \& Textiles in Eastern Europe, 19, 1 (2011).

[10] Waite, M. Sustainable textiles: The role of bamboo and a comparison of bamboo textile properties, In: JTATM, 6, 1 (2009).

[11] Schindler, W.D., Hauser, P. Chemical finishing of textiles, In: Woodhead Publishing Limited, The Textile Institute, Cambridge, England, pp. 29-42 (2004).

[12] Nostadt, K., Zyschka, R. Softeners in the Textile Finishing Industry, In: Colourage, 44, 53 (1997).

[13] Juodsnukytè, D., Gutauskas, M., Krauledas, S. Influence of fabric softeners on performance stability of the textile materials, In: Mater Sci+, 11, 179 (2005).

[14] Agarwal, G., Koehl, L., Perwuelz, A. The influence of constructional properties of knitted fabrics on cationic softener pick up and deposition uniformity, In: Text Res J, 80, 1432 (2010).

[15] Wahle, B., Falkowski, J. Softeners in textile processing Part I: An overview, In: Rev Prog Color, 32, 118 (2002).

[16] Philippe, F., Schacher, L., Adolphe, D.C., Dacremont, C. Tactile feeling: Sensory analysis applied to textile goods, In: Text Res J, 74, 1066 (2004).

[17] Manickam, M.M. Silicone chemistry for fabric care, In: Colourage, 56, 86 (2009).

[18] Case, F. Silicones in fabric care, In: Inform, 17, 559 (2006).

[19] Ushakova, V., Van Roy, B. External validation of silicone technologies for fabric care. In: Dow Corning Europe Publications, Printed in USA, Form No. 27-1114-01, (2003).

[20] Talebpour, F., Holme, I. Effects of silicone-based softener on the easy-care finished cotton fabric, In: Indian J Fibre Text, 31, 444 (2006).

[21] G. Agarwal, L. Koehl, A. Perwuelz, Sensory study of knitted fabrics that have gone through washing cycles with domestic softener. Part I: Establishment of a panel and assessment thereof, In: Fibres Text. East. Eur, 19, 100 (2011).

[22] E. Sarioğlu, N. Çelik, Investigation on regenerated cellulosic knitted fabric performance by using silicone softeners with different particle sizes, In: Fibres Text. East. Eur, 23, 71 (2015).

[23] Lima, M., da Silva, L.F., Vasconcelos, R., Cunha, J., Frıctorq, Desıgn for the objectıve measurement of frictıon in 2D soft surfaces, In: XIII Congreso Internacional de Ingeniería de Proyectos Badajoz, 8-10 de Julio de 2009.

[24] BS EN ISO Standard, Standard Number: 9073-9, 2008.

[25] Saville, B.P. Physical testing of textiles, In: Woodhead Publishing Ltd, Cambridge England, ISBN 0849305683 , p. 310 (1999).

Authors:
GAMZE SÜPÜREN MENGÜÇ${ }^{1}$, EYLEN SEMA DALBAŞI², ARIF TANER ÖZGÜNEY²,
NILGÜN ÖZDIL ${ }^{2}$
${ }^{1}$ Ege University, Emel Akın Vocational Training School, 35040, Ege University, Bornova/lzmir
2Ege University, Faculty of Engineering, Department of Textile Engineering, 35040, Ege University, Bornova/lzmir
Corresponding author:
Prof. Dr. NILGÜN ÖZDIL
e-mail: nilgun.ozdil@ege.edu.tr

